\title{
A COMPARATIVE STUDY OF OPTICAL INTERNAL URETHROTOMY ALONE WITH OPTICAL INTERNAL URETHROTOMY PLUS STEROID FOR ANTERIOR URETHRAL STRICTURE DISEASE
}

\author{
Sivsankar Govindaraju1, Arulkumar Ettappan²
}

1 Professor, Department of Urology, Government Royapettah Hospital, Chennai, Tamilnadu, India.

${ }^{2}$ Postgraduate Student, Department of Urology, Kilpauk Medical College/Government Royapettah Hospital, Chennai, Tamilnadu, India. ABSTRACT

\section{BACKGROUND}

Urethral stricture is a relatively common urological disorder, which every urologist encounters in his regular urological practice. They pose a significant problem from both clinical and economic point of view. The aetiology of stricture of urethra has changed over time. Trauma has taken over infection as the commonest cause. The management of stricture also has evolved over the times. Despite the availability of various options for the treatment of stricture urethra, internal urethrotomy has remained a popular option among the urologists in view of its simplicity, safety and shorter learning curve.

Aims and Objectives- To compare the outcome of optical internal urethrotomy between OIU alone and OIU with steroid injection at the site of stricture by means of recurrence rate and time duration for recurrence and symptom improvement in stricture patients.

\section{MATERIALS AND METHODS}

This is a prospective, randomised, controlled study by which comparing the outcome of optical internal urethrotomy alone with urethrotomy with steroid injection in the management of stricture disease in males is done. The study done during the period of January 2016 and December 2016 at Kilpauk Medical College Hospital and Government Royapettah Hospital, Chennai.

\section{RESULTS}

In first three months, there was no recurrence in both groups. In OIU group alone, in $6^{\text {th }}$ month, 3 patients came with recurrence, 4 patients came in $9^{\text {th }}$ month, 2 patients came in $12^{\text {th }}$ month and in $15^{\text {th }}$ month totally 11 patients $(36.6 \%)$. In OIU plus steroid group 1 patient came with recurrence in $12^{\text {th }}$ month and 3 patients in $15^{\text {th }}$ month, totally 4 patients $(13.3 \%)$. The p-value was $<0.05$, which was statistically significant difference. The most common age group in both Group A and B was 41 to 50; Group A was 43.3\% and in Group was B 50\%. Comorbidities were almost similar in both groups. DM in Group A was 23.3\% and in Group B was 30\%. HT in Group A was 36.6\% and in Group B was 26.6\%.

\section{CONCLUSION}

The clinical decision of stricture-recurrence-prevention techniques should be carefully tailored to every individual patient. Steroid injection to the stricture site to avoid fibrosis is a safe and effective adjuvant therapy. No complications were noted due to the steroid injections. Despite the benefits of these materials, steroids comes on top due to its cost effectiveness, lower side effects and also widespread usage in general medicine.

\section{KEY WORDS}

Optical Internal Urethrotomy, Urethral Stricture.

HOW TO CITE THIS ARTICLE: Govindaraju S, Ettappan A. A comparative study of optical internal urethrotomy alone with optical internal urethrotomy plus steroid for anterior urethral stricture disease. J. Evolution Med. Dent. Sci. 2018;7(24):2834-2837, DOI: 10.14260/jemds/2018/639

\section{BACKGROUND}

Urethral stricture in the male still presents as one of the most common and challenging problems to the urologist. Treatment options include dilatation, endoscopic internal urethrotomy and urethroplasty. Optical internal urethrotomy followed by intermittent self-dilatation is the most commonly performed intervention for urethral stricture disease.[1] The optical internal urethrotomy offers faster recovery, less risk of infection and is minimally invasive.[2,3] The aetiology of stricture urethra has changed over times.

'Financial or Other Competing Interest': None.

Submission 30-04-2018, Peer Review 25-05-2018,

Acceptance 31-05-2018, Published 11-06-2018.

Corresponding Author:

Dr. Arulkumar Ettappan,

Postgraduate Student,

Department of Urology,

Kilpauk Medical College Hospital,

Kilpauk, Chennai-10, Tamilnadu, India.

E-mail:k.arul21@yahoo.in

DOI: $10.14260 /$ jemds $/ 2018 / 639$
Trauma has taken over infection as the commonest cause. The trauma can be either External (Trauma) or Internal (Instrumentation). Another important cause is Balanitis Xerotica Obliterans, also known as Lichen Sclerosus. In a small group of patients, no particular cause can be made out and they are grouped under 'idiopathic.' Optical Internal Urethrotomy (OIU) is best suited for single bulbar strictures, shorter than $2 \mathrm{cms}^{[4,5]}$ with minimal spongiofibrosis and with no past internal urethrotomy. Optical Internal Urethrotomy (OIU) may be contraindicated in suspected urethral malignancy, coagulation disorders or active infection. Optical Internal Urethrotomy (OIU) is not suited for long strictures (>2 cms), multiple strictures, previous optical internal urethrotomy (OIU) and strictures other than bulbar.

\section{Aim of the Study}

To compare the outcome of optical internal urethrotomy between OIU alone and OIU with steroid injection at the site of stricture by means of recurrence rate and time duration for recurrence and symptom improvement in stricture patients. 


\section{MATERIALS AND METHODS}

This is a prospective, randomised, controlled study by which comparing the outcome of optical internal urethrotomy alone with urethrotomy with steroid injection in the management of stricture disease in males. The study was done between the period of January 2016 and December 2016 at Kilpauk Medical College Hospital and Government Royapettah Hospital, Chennai.

Totally, 60 patients were included in this study between the age group of 30 and 60 years of age. The sample size was taken as per our convenience. The patients were randomised into two groups using computer generated random numbers table. The same surgeons have done all the procedures in both groups. Group A underwent optical internal urethrotomy alone and for Group B optical internal urethrotomy with methylprednisolone injection was injected at the site of stricture.

\section{Inclusion Criteria}

- $\quad$ Symptomatic anterior urethral (bulbar) stricture $<2 \mathrm{~cm}$.

- Partially obliterated anterior urethral stricture.

- Patients who are willing and compliant for the study.

\section{Exclusion Criteria}

Patients with neurological deficit, bladder stone, enlarged prostate and meatal stenosis, complete obliteration of the bulbar urethra, multiple stricture or previous urethroplasty.

\section{Methodology}

Informed consent. Randomised into Group A and B based on simple random sampling method-

Group A

30 patients underwent OIU alone.

\section{Group B}

30 patients underwent $\mathrm{OIU}+$ methylprednisolone injection at the site of stricture.

The procedure was performed under general or spinal anaesthesia. Patients were placed in lithotomy position. A $21 \mathrm{Fr}$ optical internal urethrotomy with 0 degree telescope was introduced into the urethra under the guidance of a guidewire to act as a guide for accurate cutting across the stricture. The stricture was incised at 12 o'clock positions cutting through the entire fibrous tissue until the urethroscope passed easily into the urinary bladder.

After doing OIU $40 \mathrm{mg}$ of methylprednisolone was injected with $3.7 \mathrm{fr} 37 \mathrm{~cm}$ needle at the site of stricture submucosally in Group B patients.

All patients were followed up for 15 months based on history, examination, uroflowmetry at 3 months interval and ascending urethrogram at 6 months interval.

Recurrence defined as patient complaining of strain to void and uroflow shows Q-max $<10 \mathrm{~mL} / \mathrm{sec}$ and AUG shows narrowing in the bulbar urethra.

Results on categorical measurements are presented in percentage. Chi-square test has been used to find the significance of study parameters on categorical scale between two groups. Student's ' $\mathrm{t}$ ' test has been used to determine the significance between two group means. All analyses were two tailed and $\mathrm{p}<0.05$ was considered significant. SPSS version 16.0 was used for data analysis.

\section{RESULTS}

\begin{tabular}{|c|c|c|c|}
\hline $\begin{array}{r}\text { Sl. } \\
\text { No. }\end{array}$ & Age Group & Group A & Group B \\
\hline 1 & $30-40$ & $8(26.6 \%)$ & $7(23.3 \%)$ \\
\hline 2 & $41-50$ & $13(43.3 \%)$ & $15(50 \%)$ \\
\hline 3 & $51-60$ & $9(30 \%)$ & $8(26.6 \%)$ \\
\hline \multicolumn{3}{|c|}{ Table 1. Age Distribution } \\
\hline
\end{tabular}

The most common age group in both Group A and B is 41 to 50 .

\begin{tabular}{|c|c|c|c|}
\hline Group & $\begin{array}{c}\text { No. of } \\
\text { Patients }\end{array}$ & $\begin{array}{c}\text { Mean Age in } \\
\text { Years }\end{array}$ & $\begin{array}{c}\text { Standard } \\
\text { Deviation }\end{array}$ \\
\hline Group A & 30 & 44.33 & 8.02725 \\
\hline Group B & 30 & 43.87 & 8.62128 \\
\hline \multicolumn{4}{|c|}{ Table 2 } \\
\hline
\end{tabular}

When statistically compared for age in both the groups, the p-value is 0.8290 which is statistically insignificant. Hence, both groups were comparable with regarding to age.

\begin{tabular}{|c|c|c|c|c|}
\hline Group & $\begin{array}{c}\text { No. of } \\
\text { Patients }\end{array}$ & Group A & Group B & P value \\
\hline $\begin{array}{c}\text { Diabetes } \\
\text { Mellitus }\end{array}$ & 16 & $7(23.3 \%)$ & $9(30 \%)$ & 0.7720 \\
\hline Hypertension & 19 & $11(36.6 \%)$ & $8(26.6 \%)$ & 0.6544 \\
\hline \multicolumn{5}{|c|}{ Table 3. Co-Morbidities } \\
\hline
\end{tabular}

Comorbidities are almost similar in both groups. DM in Group A was 23.3\% and in Group B was 30\%. HT in Group A was $36.6 \%$ and in Group B was $26.6 \%$.

The two groups were statistically comparable with regarding to age and comorbidities.

In our study out of 30 patients who underwent OIU alone, 11 patients had recurrent stricture disease. In OIU with steroid group, only 4 patients had recurrent stricture out of 30 patients. Early recurrence is more common in Group A patients. In Group B patients, the recurrence rate is very low and the period for recurrence is also prolonged.

\begin{tabular}{|c|c|c|}
\hline Recurrence & OIU & OIU + Steroids \\
\hline 3 Months & NIL & NIL \\
\hline 6 Months & 3 & NIL \\
\hline 9 Months & 4 & NIL \\
\hline 12 Months & 2 & 1 \\
\hline 15 Months & 2 & 3 \\
\hline Total & $\mathbf{1 1 ( 3 6 . 6 \% )}$ & $\mathbf{4 ( 1 3 . 3 \% )}$ \\
\hline \multicolumn{3}{|c|}{ Table 4 } \\
\hline
\end{tabular}

First three months, there was no recurrence in both groups.

In OIU alone group in $6^{\text {th }}$ month 3 patients came with recurrence, 4 patients in $9^{\text {th }}$ month, 2 patients in $12^{\text {th }}$ month and $15^{\text {th }}$ month totally in 11 patients $(36.6 \%)$.

In OIU plus steroid group, one patient came with recurrence in $12^{\text {th }}$ month and 3 patients in $15^{\text {th }}$ month. Totally, 4 patients $(13.3 \%)$. The p-value is $<0.05$, which was the statistically significant difference. 
The most common age group in both Group A and B was 41 to 50 and Group A was $43.3 \%$ and in Group B was 50\%.

Comorbidities are almost similar in both groups. DM in Group A was 23.3\% and in Group B was 30\%. HT in Group A was $36.6 \%$ and in Group B was 26.6\%.

\section{DISCUSSION}

Urethral stricture is a well-known disease that has been known for centuries. Difficulty on managing urethral strictures is its tendency to recur. First leading cause of urethral strictures was infection, but even with development of mankind and technologies iatrogenic instrumentations and external trauma take the lead. The actual incidence of urethral strictures developed after the transurethral resection of prostate of $2 \%-10 \%$ as well as radical $(8.4 \%)$ and simple $(1.9 \%)$ prostatectomies $(2-4)$. There are many treatment modalities as dilatation, endoscopic urethrotomy, stent placement and urethroplasty. Internal urethrotomy (IU) and dilatation are widely used for urethral strictures less than $2 \mathrm{~cm}$ with a success rate of $70 \%$, but also have a high rate of stricture recurrence. [6,7] Although, open urethroplasty is a highly successful and durable treatment method, surgeons do not perform it so often due to its invasiveness, longer catheterisation requirement and need of experienced surgery skills. The recurrence of stricture occurs as a result of scar that forms into the urethral epithelium and decreases the calibre of urethra.[8,9] There are many investigations about use of drugs such as steroids, Mitomycin C, Hyaluronidase to avoid this scar or keloid formation. ${ }^{[10,11]} \mathrm{We}$ aimed to investigate the combination of steroid injection with IU in order to avoid the recurrence of strictures and cure the patient with minimally invasive treatment.

Internal urethrotomy is a safe first line treatment for urethral strictures, independent of aetiology and location with an overall primary success rate of $60 \%-70 \%$. Endoscopic treatment is recommended before various forms of urethroplasty. Ho: YAG laser urethrotomy is a safe and effective minimally invasive therapeutic modality for urethral stricture with results comparable to those of conventional urethrotomy.[12,13]

In intervention for recurrent urethral stricture holmium laser treatment is safe and effective. Application of steroid at time of urethrotomy produces better result than urethrotomy alone.[14,15] Mitomycin C is useful in delaying the healing process by preventing replication of fibroblasts and epithelial cells and inhibiting collagen synthesis. It is also proposed that it can delay wound contraction.[16] Hyaluronidase instillation during OIU may decrease the incidence of urethral stricture recurrence. Intralesional injection decreases fibroblast proliferation, collagen and glycosaminoglycan synthesis and suppresses pro-inflammatory mediators in wound healing process.[17]

The main problem of urologists in relation to the urethral stricture disease is not the disease itself, but its nature of recurrence.[18] Optical internal urethrotomy is a minimally invasive and repeatable procedure with varying success rates, but not as good as urethroplasty. Open urethroplasty has better results if performed at early stage, but recurrent OIU decreases the success rate of urethroplasty.[8,9] The main pathogenesis of stricture is the fibrosis formation caused by excessive collagen synthesis and changes in the extracellular matrix of the urethral lumen due to the endoscopic instrumentation, trauma and infections. Spongiofibrosis occurs in varying degrees and narrows the urethral lumen so that there are some ideas to treating the fibrosis with antifibrotic agents such as hyaluronidase, mitomycin C, bitoxin $\mathrm{A},[19]$ captopril,[20] docetaxel,[21] somatostatin analogues[22] and steroids. There are many studies that have come with OIU along with injection triamcinolone. With varying success rate, we have done this study with injection methylprednisolone. In this study, we observed that steroid injection decreases the recurrence rate and also prolonged the recurrence time significantly.

In addition to that, we removed the catheter at $5^{\text {th }}$ day after surgery.

\section{Limitation}

In the present study the sample size is small, because of short study period.

\section{CONCLUSION}

The clinical decision of stricture-recurrence-prevention techniques should be carefully tailored to every individual patient. Steroid injection to the stricture site to avoid fibrosis is a safe and effective adjuvant therapy. No complications were noted due to the steroid injections. Despite the benefits of these materials, steroids comes on top due to its cost effectiveness, lower side effects and also widespread usage in general medicine. Methylprednisolone injection during internal urethrotomy may decrease the recurrence rate significantly. As the course of urethral stricture recurrence is rather long spreading over many years, further comparative studies with longer follow-ups are required to accurately evaluate the effect of steroid injection.

\section{REFERENCES}

[1] Naude AM, Heyns CF. What is the place of internal urethrotomy in the treatment of urethral stricture disease? Nat Clin Pract Urol 2005;2(11):538-45.

[2] Albers P, Fitchner J, Bruhl P, et al. Long term results of internal urethrotomy. J Urol 1996;156(5):1611-4.

[3] Chilton CP, Shah PJ, Fowler CG, et al. The impact of optical urethrotomy on the management of urethral stricutres. Br J Urol 1983;55(6):705-10.

[4] Ferguson GG, Bullock TL, Anderson RE, et al. Minimally invasive methods for bulbar urethral strictures: a survey of members of the American Urological Association. Urology 2011;78(3):701-6.

[5] Latini JM. Minimally invasive treatment of urethral strictures in men. Current Bladder Dysfunction Reports 2008;3(2):111-6.

[6] Holm-Nielsen A, Schultz A, Moller-Pedersen V. Direct vision internal urethrotomy: a critical review of 365 operations. Br J Urol 1984;56(3):308-12.

[7] Santucci R, Eisenberg L. Urethrotomy has a much lower success rate than previously reported. J Urol 2010;183(5):1859-62.

[8] Langston JP, Robson CH, Rice KR, et al. Synchronous urethral stricture reconstruction via 1-stage ascending approach: rationale and results. J Urol 2009;181(5):2161-5. 
[9] Roehrborn CG, McConnell JD. Analysis of factors contributing to success or failure of 1-stage urethroplasty for urethral stricture disease. J Urol 1994;151(4):869-74.

[10] Kumar S, Garg N, Singh SK, et al. Efficacy of optical internal urethrotomy and intralesional injection of Vatsala-Santosh PGI tri-inject (Triamcinolone, Mitomycin C, and Hyaluronidase) in the treatment of anterior urethral stricture. Adv Urol 2014;2014:192710.

[11] Hradec E, Jarolim L, Petrik R. Optical internal urethrotomy for strictures of the male urethra: effect of local steroid injection. Eur Urol 1981;7(3):165-8.

[12] Jain SK, Kaza RC, Singh BK. Evaluation of holmium laser versus cold knife in optical internal urethrotomy for the management of short segment urethral stricture. Urol Ann 2014;6(4):328-33.

[13] Kumar S, Kapoor A, Ganesamoni R, et al. Efficacy of holmium laser urethrotomy in combination with intralesional triamcinolone in the treatment of anterior urethral stricture. Korean J Urol 2012;53(9):614-8.

[14] Korhonen P, Talja M, Ruutu M, et al. Intralesional corticosteroid injections in combination with internal urethrotomy in the treatment of urethral strictures. Int Urol Nephrol 1990;22(3):263-9.

[15] Tabassi TK, Yarmohamadi A, Mohammadi S. Triamcinolone injection following internal urethrotomy for treatment of urethral stricture. Urol J 2011;8(2):132-6.
[16] Mazdak H, Meshki I, Ghassami F. Effect of mitomycin C on anterior urethral stricture recurrence after internal urethrotomy. Eur Urol 2007;51(4):1089-92.

[17] Chung JH, Kang DH, Choi HY, et al. The effects of hyaluronic acid and carboxymethylcellulose in preventing recurrence of urethral stricture after endoscopic internal urethrotomy: a multicenter, randomized controlled, single-blinded study. J Endourol 2013;27(6):756-62.

[18] Pansodoro V, Emiliozzi P. Internal urethrotomy in the management of anterior urethral strictures: long term follow-up. J Urol 1996;156(1):73-5.

[19] Khera M, Boone TB, Smith CP. Botulinum toxin type A: a novel approach to the treatment of recurrent urethral strictures. J Urol 2004;172(2):574-5.

[20] Shirazi M, Khezri A, Samani SM, et al. Effect of intraurethral captopril gel on the recurrence of urethral stricture after direct vision internal urethrotomy: Phase II clinical trial. Int J Urol 2007;14(3):203-8.

[21] Fu D, Chong T, Li H, et al. Docetaxel inhibits urethral stricture formation, an initial study in rabbit model. PLoS One 2014;9(11):e112097.

[22] Andersen HL, Duch BU, Gregersen H, et al. The effect of the somatostatin analogue lanreotide on the prevention of urethral strictures in a rabbit model. Urol Res 2003;31(1):25-31. 